\title{
Location of the maximum scouring depth at the outlet of partially- blocked and non-blocked box culvert
}

\author{
S.Sorourian \\ A.Keshavarzi \\ J. Ball \\ B.Samali \\ School of civil and Environmental Engineering, University of Technology Sydney, Australia
}

\begin{abstract}
Among various hydraulic structures, culvert is the most likely one which usually blocks by the debris that are carrying by flow during large flood events. The size of the structure and its location where a waterway crosses a road or railway increases the possibility of clogging. The blockage of culvert accelerates bed scouring at the outlet hence affects bed scouring profile. This leads to increase the risk of culvert collapsed and produce different kinds of damages to the society. The present study concerns the effect of upstream blockage on the scouring profile at the outlet of a box culvert. Therefore, the experimental program was designed to investigate the relationship between the scouring geometry and blockage ratio. The experimental tests were carried out under non-blocked and partially blocked conditions. The sediment material used in this study was uniform non-cohesive sand material. Results showed that the scouring bed profile is different in partially blocked condition when compared to the non-blocked condition. Additionally it was found that the maximum scouring depth in a partially blocked culvert occurred at a distance very close to the outlet of the box culvert.
\end{abstract}

\section{INTRODUCTION}

Culverts are locations in water courses where a construction occurs and therefore where blockage of some type is likely to occur. Weeks et al. (2009) reported the damage of culverts and waterways as an impact of these structures blockage.

Rigby et al. (2002) worked on blockage of bridges and culverts and found out that when the opening size of culverts is less than $6 \mathrm{~m}$ (measured diagonally) there is a high risk of culvert blockage. Barthelmess and Rigby (2011) estimated culvert and bridge blockage based on debris availability, mobility and transportability factors. Rigby and Barthelmess (2011) explored culvert blockage mechanisms and their impact on flood behaviour. They pointed out that one consequence of blockage is flow diversions to the private properties as the passage is blocked by the debris. Even small blockages created diversions that would not usually occur and considerably change flood behaviour.

The early studies on the nature of scouring beginning with Rouse (1938) and Laursen (1952) and followed by Smith (1957). Bohan (1970) investigated scour dimensions at the culvert outlet in large scale models. Abt et al. (1986) studied culverts slope influences scouring depth at outlet of the culvert and pointed out that a sloped culvert can increase the maximum scour depth from 10 to $40 \%$ over the scour dimensions for a horizontal culvert. Abt et al.(1987) investigated the influence of culvert shape on outlet scour and determined that dimensions of scour developed at the outlet of circular shaped culverts are significantly varies from other shapes of culverts. They developed an equation to correlate the maximum scour depth to modified discharge intensity. Ali and Lim (1986) investigated the effects of changing tail-water depth on scouring downstream the jet. Abt et al. (1996) estimated the dimension of outlet scour in relation to culvert discharge, hydraulic radius, time and material gradation. The effect of culvert slope and outlet drop is also considered in this equation. Although this formula is quite comprehensive but it lacks simplicity. Abida and Townsend (1991) developed an equation for local scour downstream of box-culverts relating flow Froude number and sediment size. Lim (1995) conducted experimental tests on a circular un-submerged culvert. He compared his work with Abt et al. (1984) and Breusers and Raudkivi(1991) and stated that the range of applicability and limitations of those formulations are highlighted comparing with his work and some relevant data from other researchers. He proposed equations to envelope these data based on sediment densimetric Froude number. Day et al. (2001) investigated the effects of tail water depth and model 
scale on maximum depth of scouring based on experimental test of circular culverts. Liriano et al. (2002) studied scour at culverts influenced by turbulent flow and pointed out that the peak values of turbulence intensities over the fixed bed coincide with the location of the maximum scour depth for the fully developed scour hole. Emami and Schleiss (2010) conducted some experimental tests to evaluate the natural mobile bed erosion without any protection. They compared their work with some previous studies and proposed equation for maximum scour depth based on their experimental tests.

According to previous studies it can be concluded that main factors influencing the maximum scour depth downstream of culverts are recognized as sediment properties such as median grain size and geometrical standard deviation, flow conditions and depth of tail water. Some research also indicated that geometry of the culvert and its slope also affects the formation of scour hole. Most formulas proposed in this regard are function of densimetric Froude number, median grain size of bed material, depth of water downstream the culvert and size of culvert opening. In all of previous studies, it is attempted to consider scoring pattern at the outlet of culvert in a non-blocked condition, however, in flood events the culverts are not usually works in non-blocked condition as they are partially blocked by the debris. Therefore, the focus of this study is to investigate the flow characteristics and scouring pattern in a partially blocked condition and the results are reported in this paper

\section{EXPERIMENTAL SET UP}

An experimental program was designed to investigate the relationship between the maximum scour depth, blockage ratio of the culvert and flow characteristics. The experimental tests were carried on, in two different conditions; non-blocked and partially blocked condition and the effect of culvert blockage are studied. The sediment material used in this study is uniform non-cohesive sand. The median grain size for sands equals $0.85 \mathrm{~mm}$ and $2.0 \mathrm{~mm}$.

Experimental tests conducted in the scour testing facility depicted in Figure 1. Water was supplied to the static tank from the laboratory supply. The water introduced to the flume through a valve which controls the water flow rate, and then it runs through the box-culvert that is settled in the sand basin. At the end of the flume a sluice gate is installed to the downstream water depth and velocity.

The flume in UTS Hydraulic Laboratory is a 19 $m$ long concrete flume. The width and depth of the flume are $605 \mathrm{~mm}$ and $600 \mathrm{~mm}$, respectively. A test section with the length of $4 \mathrm{~m}$ is provided at a distance of $9 \mathrm{~m}$ from the entrance. The thickness of the bed material in the test section was $150 \mathrm{~mm}$. The culvert model is shown in Figure 2. The opening of culvert is $200 \times 200 \mathrm{~mm}$ and the length of culvert's barrel is $900 \mathrm{~mm}$. There are transitions with $30^{\circ}$ flare at the inlet and outlet of the culvert. To make the blockage a plate was installed at the opening of the culvert. Two sizes of plates $(200 \times 80 \mathrm{~mm}$ and $200 \times 120 \mathrm{~mm}$ ) were used so far to get the variant blockage ratio in the experimental tests.

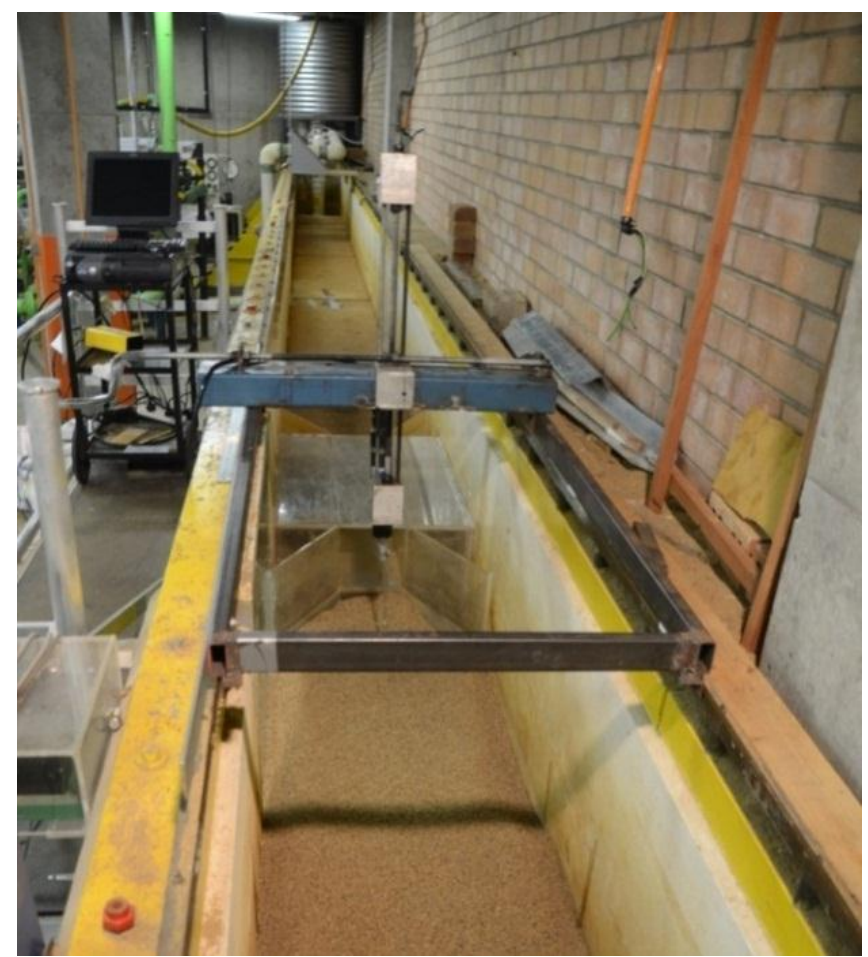

Figure 1 Experimental test facility in Hydraulics Laboratory
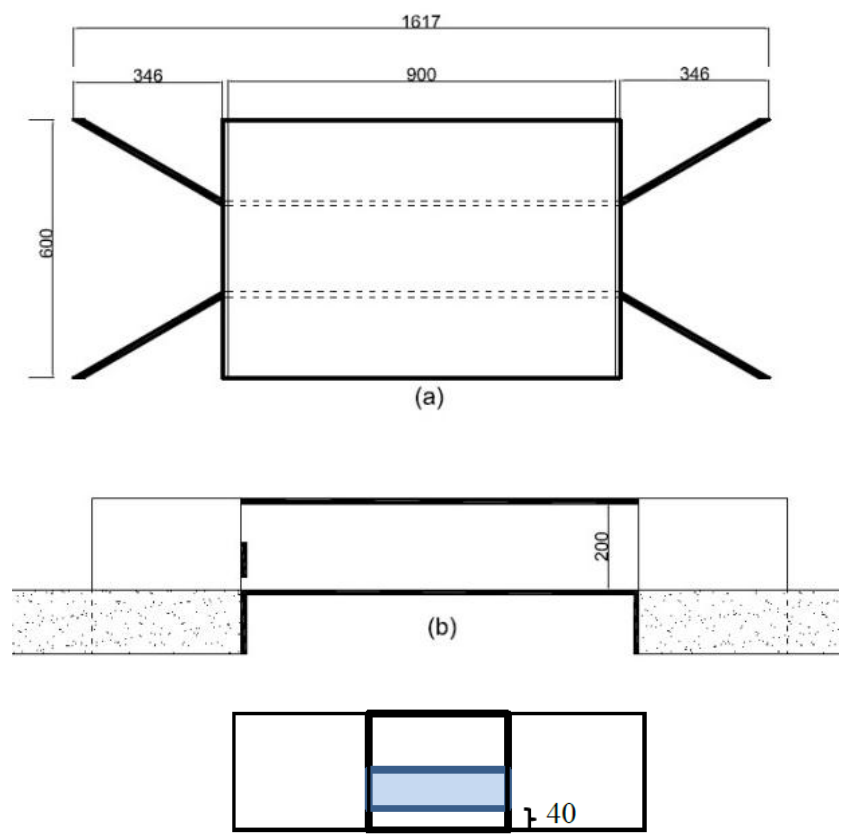

(c)

Figure 2 Culvert model; (a) Plan view (b) Profile view (c) inlet view (all units are in $\mathrm{mm}$ ) 
Table 1 depicts the flow conditions, sediment properties and test classifications. In this table $H$ is the depth of water at the outlet of the culvert, $h_{u}$ is the upstream water level, $h_{t}$ represents the tail water depth and $F_{d}$ is the densimetric Froude number.
The blockage of culvert is represent by $B$ which defines as $\left(h_{B} / h_{u}\right)$ where $h_{B}$ is the height of the plate used as the blockage in the inlet of culvert.

Table 1Test classification for the experimental tests

\begin{tabular}{|c|c|c|c|c|c|c|c|c|c|c|}
\hline Test & $\begin{array}{l}d_{50} \\
(\mathrm{~mm})\end{array}$ & $\sigma_{g}$ & $\begin{array}{l}h_{B} \\
(\mathrm{~mm})\end{array}$ & $\begin{array}{l}H \\
(\mathrm{~mm})\end{array}$ & $\begin{array}{l}h_{t} \\
(\mathrm{~mm})\end{array}$ & $\begin{array}{l}h_{u} \\
(\mathrm{~mm})\end{array}$ & $\begin{array}{l}Q \\
(\mathrm{lit} / \mathrm{s})\end{array}$ & $B$ & $F_{d}$ & $\begin{array}{l}d_{s m} \\
(\mathrm{~mm})\end{array}$ \\
\hline S2B01 & 2 & 1.23 & 0 & 125 & 125 & 125 & 10.1 & 0 & 2.2 & 240 \\
\hline S2B02 & 2 & 1.23 & 0 & 155 & 155 & 155 & 12.3 & 0 & 2.2 & 255 \\
\hline S2B03 & 2 & 1.23 & 0 & 100 & 105 & 105 & 12.8 & 0 & 3.6 & 250 \\
\hline S2B04 & 2 & 1.23 & 0 & 120 & 120 & 120 & 8.6 & 0 & 2 & 210 \\
\hline S2B05 & 2 & 1.23 & 0 & 100 & 105 & 100 & 6.6 & 0 & 1.8 & 250 \\
\hline S1B01* & 0.85 & 1.37 & 0 & 200 & 197 & 198 & 14.61 & 0 & 2 & 280 \\
\hline S1B02 & 0.85 & 1.37 & 0 & 157 & 157 & 160 & 15 & 0 & 2.7 & 270 \\
\hline S1B03 & 0.85 & 1.37 & 0 & 170 & 170 & 174 & 18.7 & 0 & 3.1 & 270 \\
\hline S1B04 & 0.85 & 1.37 & 0 & 138 & 145 & 150 & 13.2 & 0 & 2.7 & 240 \\
\hline $\mathrm{S} 1 \mathrm{~B} 05^{* *}$ & 0.85 & 1.37 & 0 & 95 & 108 & 95 & 14.2 & 0 & 4.2 & 360 \\
\hline S1B06 & 0.85 & 1.37 & 0 & 90 & 95 & 90 & 4.9 & 0 & 1.5 & 255 \\
\hline S1B07 & 0.85 & 1.37 & 0 & 55 & 50 & 75 & 7.04 & 0 & 3.6 & 135 \\
\hline VS1B04 & 0.85 & 1.37 & 0 & 148 & 148 & 147 & 7.25 & 0 & 1.4 & ----- \\
\hline VS1B05 & 0.85 & 1.37 & 0 & 142 & 142 & 142 & 7.8 & 0 & 2.4 & ----- \\
\hline S2B401 & 2 & 1.23 & 80 & 140 & 145 & 170 & 10.7 & 0.5 & 2.1 & 240 \\
\hline S2B402 & 2 & 1.23 & 80 & 155 & 160 & 185 & 12.3 & 0.4 & 2.2 & 250 \\
\hline S2B403 & 2 & 1.23 & 80 & 105 & 105 & 175 & 12.8 & 0.5 & 3.4 & 240 \\
\hline S2B404 & 2 & 1.23 & 80 & 110 & 115 & 145 & 8.8 & 0.6 & 2.2 & 240 \\
\hline S2B405 & 2 & 1.23 & 80 & 105 & 110 & 125 & 6.6 & 0.6 & 1.7 & 250 \\
\hline S1B401* & 0.85 & 1.37 & 80 & 195 & 195 & 210 & 14.67 & 0.4 & 2.1 & 265 \\
\hline S1B402 & 0.85 & 1.37 & 80 & 165 & 168 & 196 & 14.61 & 0.4 & 2.5 & 240 \\
\hline S1B403* & 0.85 & 1.37 & 80 & 60 & 60 & 195 & 15.12 & 0.4 & 7 & 300 \\
\hline S1B405 & 0.85 & 1.37 & 80 & 210 & 213 & 230 & 19.8 & 0.3 & 2.6 & 300 \\
\hline S1B406* & 0.85 & 1.37 & 80 & 150 & 145 & 200 & 20.65 & 0.4 & 3.8 & 260 \\
\hline S1B407* & 0.85 & 1.37 & 80 & 80 & 70 & 230 & 25 & 0.3 & 8.7 & 30 \\
\hline S1B408 & 0.85 & 1.37 & 80 & 70 & 70 & 120 & 4.86 & 0.7 & 1.9 & 210 \\
\hline S1B409 & 0.85 & 1.37 & 80 & 80 & 95 & 160 & 10.11 & 0.5 & 3.5 & 180 \\
\hline VS1B403 & 0.85 & 1.37 & 80 & 147 & 147 & 160 & 7.2 & 0.5 & 1.4 & ----- \\
\hline VS1B405 & 0.85 & 1.37 & 80 & 143 & 143 & 153 & 7.8 & 0.5 & 2.4 & ----- \\
\hline S2B601 & 2 & 1.23 & 120 & 130 & 130 & 190 & 10.3 & 0.6 & 2.2 & 270 \\
\hline S2B602 & 2 & 1.23 & 120 & 170 & 170 & 210 & 12.5 & 0.6 & 2 & 250 \\
\hline S2B603 & 2 & 1.23 & 120 & 50 & 100 & 195 & 12.8 & 0.6 & 7.1 & 240 \\
\hline S2B604 & 2 & 1.23 & 120 & 110 & 115 & 160 & 8.8 & 0.8 & 2.2 & 250 \\
\hline S2B605 & 2 & 1.23 & 120 & 90 & 105 & 135 & 6.6 & 0.9 & 2 & 255 \\
\hline S1B601 & 0.85 & 1.37 & 120 & 60 & 70 & 150 & 7 & 0.8 & 5 & 280 \\
\hline
\end{tabular}

* Culvert without transition 


\section{RESULTS AND DISCUSSION}

\subsection{Flow structure}

Figure 3 shows the distribution of streamwise velocity in a $30 \mathrm{~mm}$ layer $(z)$ of flow from the bed to water surface in non-blocked (VS1B04) and blocked situation (VS1B403) under similar flow condition. Coordinate $X$ shows the distance from the inlet of the culvert in flow direction. Flow velocity was measured in the culvert from the inlet $(x=0)$ to 600 $\mathrm{mm}$ after the outlet of the culvert $(x=1500)$ under fixed bed condition. Flow velocity was measured on the centerline of the culvert.
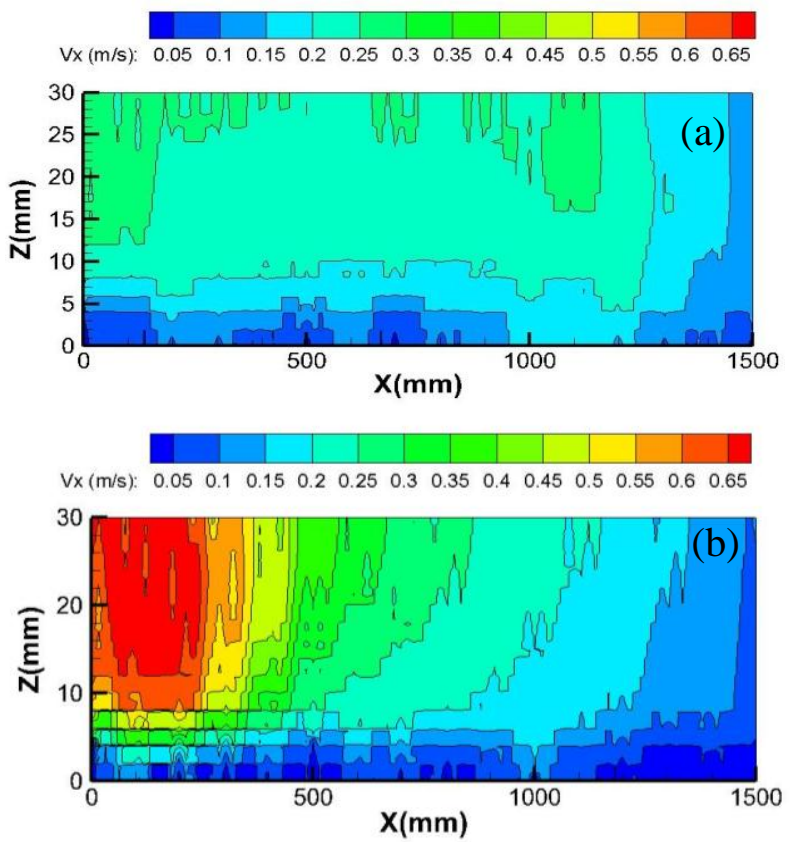

Figure 3 Velocity distributions in the $30 \mathrm{~mm}$ layer from the bed of the culvert; (a) non-blocked (b) partially blocked

As shown in Figure 3, in a non-blocked condition the distribution of the streamwise velocity is more uniform while in a partially blocked condition the gradation of velocity rapidly changes. The maximum velocity in the streamwise direction for non-blocked condition is $0.26 \mathrm{~m} / \mathrm{s}$ but it increases to $0.65(\mathrm{~m} / \mathrm{s})$ in partially blocked condition which is 2.5 times more than non-blocked condition.

Figure 4 shows the flow structure for two set of experimental tests. Set1 includes test VS1B04 (nonblocked) and VS1B403 (blocked) and the set 2 includes VS1B05 (non-blocked) and VS1B405 (blocked). Each set of the tests were conducted in the same flow condition (Table 1).

Figure 4a shows the normalized turbulent intensity $\left(T I_{x} / U_{*}\right)$ in $X$ direction at the outlet of the culvert $(x=900 \mathrm{~mm})$ versus normalized depth $(z / H) . z$ is depth of water from the bed, $H$ is total water depth and $U_{*}$ is shear velocity. The normalized turbulent intensity at the outlet of the culvert for the blocked condition is more than non-blocked condition in both set of tests. The normalized turbulent intensity of blocked condition equals 1.90 and 2.7 for set 1 and 2 , respectively. This parameter decreases to 0.76 and 1.15 in non-blocked condition (Figure 4a).
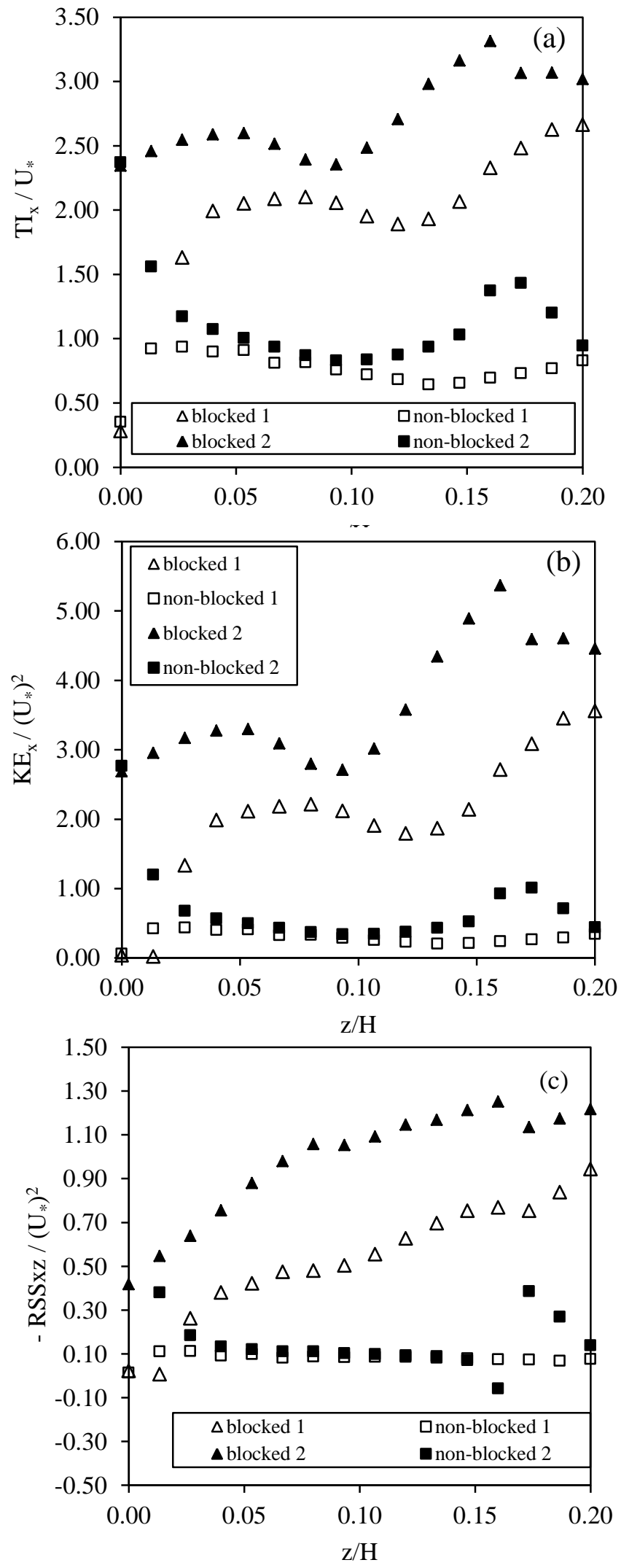

Figure 4 Flow structure of blocked and non-blocked condition at the outlet of the culvert; (a) Turbulent Intensity (b) Turbulent Kinetic Energy (c) Reynolds Shear Stress 
The normalized turbulent kinetic energy $\left(K E_{x} / U_{*}^{2}\right)$ of the flow in non-block condition of set 2 is around 0.3 and not much change was observed. Likewise, the non-blocked condition of set 2 was around 0.7. Comparing the normalized kinetic energy in blocked with non-blocked condition there is 6.7 and 5.3 times increase for set 1 and 2, respectively (Figure 4 b).

Figure $4 \mathrm{c}$ shows the normalized Reynolds shear stress versus normalized water depth, at the outlet of the culvert. Normalized Reynolds shear stress is defined as:

$$
\frac{R S S_{x z}}{U_{*}^{2}}=\frac{\overline{v_{x}^{\prime} v_{z}^{\prime}}}{U_{*}^{2}}
$$

In Equation (1), $v_{x}^{\prime}$ is flow velocity turbulence in $X$ direction and $v_{z}^{\prime}$ is flow velocity turbulence in $Z$ direction. Normalized Reynolds shear stress for nonblocked condition of both sets is around -0.1 while it reaches to -0.9 in blocked condition set1, and to 1.22 in blocked condition set 2 (Figure 4c).

\subsection{Location of scouring hole}

Figure 5 depicts the normalized profile of scouring in blocked and non-blocked conditions.
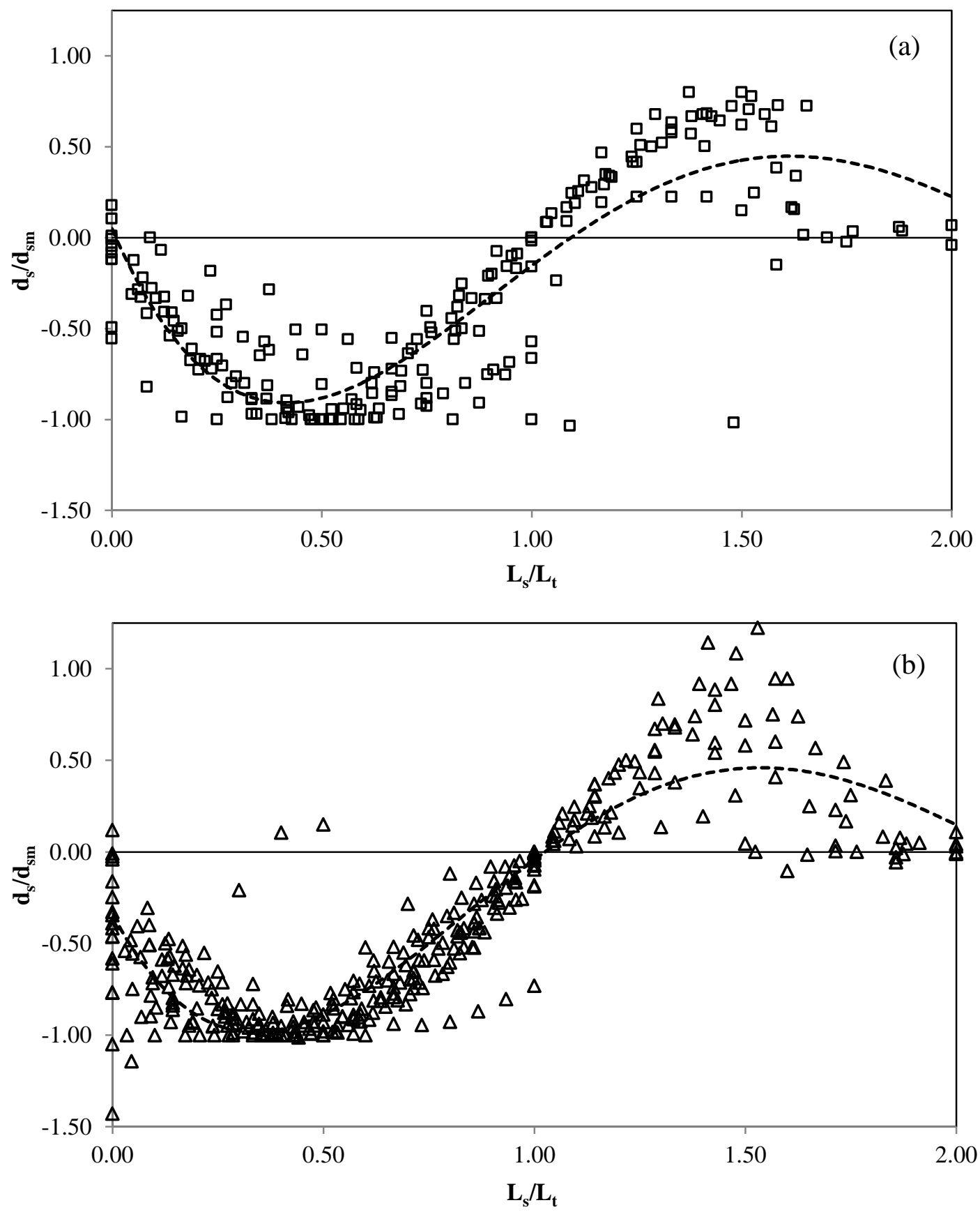

Figure 5 Normalized scouring profile; (a) non-blocked condition (b) blocked condition 
Both profiles were estimated by a quartic polynomial. Equation (2) is for the non-blocked condition (Figure 5a):

$$
\left(\frac{d_{s}}{d_{s m}}\right)=0.78\left(\frac{L_{s}}{L_{t}}\right)^{4}-4.76\left(\frac{L_{s}}{L_{t}}\right)^{3}+9.09\left(\frac{L_{s}}{L_{t}}\right)^{2}-5.31\left(\frac{L_{s}}{L_{t}}\right)-0.05
$$

In this equation, $d_{s}$ is scouring depth at any location along $x$ direction; $d_{s m}$ is the maximum scouring depth; $L_{s}$ is the location of maximum scouring depth along the $x$ direction and $L_{t}$ is the total length of scouring hole. According to the Figure 5equation (2) the maximum scouring depth occurs at a location of 0.42 total scouring lengths $\left(L_{t}\right)$. Also, at the outlet of culvert $\left(L_{s} / L_{t}=0\right)$, the scouring depth of the non-blocked condition equals to 0.05 of maximum scouring depths.

Equation (3) shows the estimated equation for scouring profile in blocked condition (Figure $5 b$ ):

$$
\left(\frac{d_{s}}{d_{s m}}\right)=0.85\left(\frac{L_{s}}{L_{t}}\right)^{4}-4.87\left(\frac{L_{s}}{L_{t}}\right)^{3}+8.60\left(\frac{L_{s}}{L_{t}}\right)^{2}-4.28\left(\frac{L_{s}}{L_{t}}\right)-0.34
$$

The maximum scouring depth in this condition occurs in the 0.34 of the total scouring length which is $25 \%$ closer to the culvert outlet comparing with the non-blocked condition.

Moreover, the scouring depth at the outlet of culvert in blocked condition equals to 0.34 of maximum scouring depth. It is 6.8 times greater than the depth of scouring hole at the outlet of culvert in nonblocked condition.

\section{CONCLUSIONS}

Comparing flow structure of blocked with the nonblocked situations in the same flow condition indicated that in blocked condition, turbulent intensity is 2.5 times; kinetic energy is 5.3 to 6.7 times and Reynolds shear stress is 12 times, greater than that of non-blocked condition.

The maximum scouring depth of the partially blocked condition occurs $25 \%$ closer to the outlet of the culvert comparing to the non-blocked condition.

Comparison of non-dimensional scouring depth $\left(d_{s} / d_{s m}\right)$ for blocked and non-blocked condition indicates that at the outlet (toe) of the partially blocked culvert non dimensional scouring depth is 12 times more than non-blocked culvert.

\section{REFERENCES}

Abida, H. \& Townsend, R. 1991, 'Local Scour Downstream of Box Culvert Outlets', Journal of irrigation and drainage engineering, vol. 117 , p. 425.
Abt, S.R., Kloberdanz, R.L. \& Mendoza, C. 1984, 'Unified culvert scour determination', Journal of Hydraulic engineering, vol. 110 , no. 10 , pp. 1475-9.

Abt, S.R., Ruff, J., Doehring, F. \& Donnell, C. 1987, 'Influence of culvert shape on outlet scour', Journal of Hydraulic engineering, vol. 113 , no. 3, pp. 393-400.

Abt, S.R., Ruff, J.F. \& Doehring, F.K. 1986, 'Culvert Slope Effects On Outlet Scour', Journal of Hydraulic Engineering, vol. 111.

Abt, S.R., Thompson, P.L. \& Lewis, T.M. 1996, 'Enhancement of the Culvert Outlet Scour Estimation Equations', Transportation Reaserch Record, no. 1523, pp. 178-85.

Ali, K. \& Lim, S. 1986, 'Local scour caused by submerged wall jets', ICE Proceedings, vol. 81, Ice Virtual Library, pp. 60745.

Barthelmess, A.J. \& Rigby, E. 2011, 'Estimating Culvert \& Bridge blockages - A Simplified Procedure', 34th World Congress of the International Association for Hydro- Environment Research and Engineering, Engineers Australia, Brisbane, Australia.

Bohan, J.P. 1970, EROSION AND RIPRAP REQUIREMENTS AT CULVERT AND STORM-DRAIN OUTLETS, DTIC Document.

Breusers, H. \& Raudkivi, A.J. 1991, Scouring, AA Balkema Rotterdam, Netherlands.

Day, R.A., Liriano, S.L. \& White, W.R. 2001, 'Effect of tailwater depth and model scale on scour at culvert outlets', Proceedings of the ICE-Water and Maritime Engineering, vol. 148, no. 3, pp. 189-98.

Emami, S. \& Schleiss, A.J. 2010, 'Prediction of Localized Scour Hole on Natural Mobile Bed at Culvert Outlets', Scour and Erosion, ASCE, pp. 844-53.

Laursen, E.M. 1952, 'Observations on the nature of scour', Proceedings of Fifth Hydraulic Conference, Bulletin, vol. 34, pp. 9-11.

Lim, S.Y. \& Lim, S. 1995, 'Scour below unsubmerged fullflowing culvert outlets', Proceedings of the ICE-Water Maritime and Energy, vol. 112, no. 2, pp. 136-49.

Liriano, S.L., Day, R.A. \& White, W.R. 2002, 'Scour at Culvert Outlets as Influenced By The Turbulent Flow Structure', Journal of Hydraulic Research, vol. 40.

Rigby, E.H. \& Barthelmess, A.J. 2011, 'Culvert Blockage Mechanisms and Their Impact On Flood Behaviour-Are All Blockages Created Equal?', 34th World Congress of the International Association for Hydro- Environment Research and Engineering, Engineers Australia, Brisbane, Australia, pp. 380-7.

Rigby, E.H., Boyd, M.J., Roso, S., Silveri, P. \& Davis, A. 2002, 'Causes and Effects of Culvert Blockage during Large Storms', paper presented to the 9th International Conference on Urban Drainage, Oregon, USA, September 8-13, 2002.

Rouse, H. 1938, 'Experiments on the mechanics of sediment suspension', Fifth International Congress for Applied Mechanics, John Wiley and Sons, Inc., New York.

Smith, G.L. 1957, 'An analysis of scour below culvert outlets', Colorado State Univ., [S.1.].

Weeks, W., Barthelmess, A., Rigby, E. \& Witheridge, G. 2009, AUSTRALIAN RAINFALL AND RUNOFF REVISON PROJECT 11: BLOCKAGE OF HYDRAULIC STRUCTURES, no. P11/S1/007 Engineers Australia. 